\title{
Effects of inorganic and organic selenium intervention on resistance of radish to arsenic stress
}

\author{
Liang $\mathrm{Hu}^{1}$, Xianglian Wang ${ }^{1 * *}$, Yuntao Zou ${ }^{1}$, Daishe $\mathrm{Wu}^{2 *}$, Guiqing Gao ${ }^{1}$, Zhiyao Zhong ${ }^{1}$, Yu Liu ${ }^{3}$, Shengming \\ $\mathrm{Hu}^{1}$, Houbao Fan ${ }^{1}$, and Baojun Zhang ${ }^{4}$ \\ ${ }^{1}$ Jiangxi Provincial Key Laboratory for Restoration of Degraded Ecosystems \& Watershed Ecohydrology, Nanchang \\ Institute of Technology, Nanchang, China; ${ }^{2}$ Key Laboratory of Poyang Lake Environment and Resource Utilization of the \\ Ministry of Education, School of Resource, Environment and Chemical Engineering, Nanchang University, Nanchang, \\ China; ${ }^{3}$ Jiangxi Biotech Vocational College, Nanchang, China; ${ }^{4} J i a n g x i$ Provincial Key Laboratory of Preventive \\ Medicine, School of Public Health, Nanchang University, Nanchang, China
}

Corresponding Authors: "*Xianglian Wang, Jiangxi Provincial Key Laboratory for Restoration of Degraded Ecosystems \& Watershed Ecohydrology, Nanchang Institute of Technology, Nanchang, China. Email: wangxianglian@nit. edu.cn; "Daishe Wu, Key Laboratory of Poyang Lake Environment and Resource Utilization of the Ministry of Education, School of Resource, Environment and Chemical Engineering, Nanchang University, Nanchang, China. Email: daishewuprof@163.com

Received: 26 July 2021; Accepted: 30 December 2021; Published: 27 January 2022

(c) 2022 Codon Publications

OPEN ACCESS (c) (i) ()요

\section{Abstract}

Arsenic (As) pollution, a potential threat for human health, in vegetables is one of the primary sources of As intake by the human body. In the Pot Experiment, the As content, physiological index and antioxidant enzyme activity of radish were determined. The results demonstrated that the order of As concentration in radish tissues was roots $>$ stems $>$ leaves. Organic selenium (Se) can inhibit the absorption of arsenic in radish more effectively than inorganic Se. The application of organic Se and low concentration of selenite (Se(IV)) significantly enhanced the stress resistance of radish for increasing superoxide dismutase and peroxidase activity, increasing soluble protein, chlorophyll and proline content, and reducing malondialdehyde content. In contrast, the high concentration of $\mathrm{Se}(\mathrm{IV})$ and selenate $(\mathrm{Se}(\mathrm{VI}))$ treatment group demonstrated stress and toxicological effects on radish. This study provides an idea for further research on the remediation mechanism of Se to As toxicity and provides a reference for the adoption of Se fertilizer in agriculture.

Keywords: arsenic toxicity, selenium intervention, radish, antioxidant enzymes

\section{Introduction}

Arsenic (As) is typically a toxic element. Vegetables are the most common food items of people's daily consumption, so their quality and safety directly affect the human health (Fendorf et al., 2010). Related reports of As pollution in vegetables have attracted much public attention (Dahal et al., 2008; Mcbride, 2013; Praveen et al., 2018). Zeng et al. (2008) reported that accumulation of As occurred in $44.2 \%$ of the soil samples taken from vegetable fields in China, and 9.2\% of the samples exceeded the safety limits. Su et al. (2005) reported that the excess rate of As pollution in vegetables in Lhasa (China) was as high as 63.64\%, and the highest As pollution index was 7.04.

Studies have established that As entering the plant interferes with various metabolic processes of the plant (Tripathi et al., 2012), causing retarded plant growth, chlorosis, membrane damage and even death. Chlorophyll content determines the photosynthetic efficiency of plants and is one of the essential indicators reflecting the growth status of plants. Under As stress, chlorophyll content was reduced in corn (Silva et al., 2015), tobacco (Wu et al., 2015) and eucalyptus (Meng 
et al., 2017). The research established that As treatment could significantly reduce the germination rate, bud, root elongation and biomass of rice seedlings (Shri et al., 2009). Under As stress, plants produce a large number of reactive oxygen species (ROS), such as superoxide anions $\left(\mathrm{O}_{2}^{-\bullet}\right)$, hydroxyl radicals $\left(\mathrm{OH}^{-\cdot}\right)$ and hydrogen peroxide $\left(\mathrm{H}_{2} \mathrm{O}_{2}\right)$. ROS can damage macromolecules such as nucleic acids, proteins and polysaccharides in cells, resulting in peroxidative damage to membrane lipids. The antioxidant enzyme system plays a vital role in removing ROS. The antioxidant enzyme system primarily includes superoxide dismutase (SOD), catalase (CAT) and peroxidase (POD) (Meng et al., 2017). Changes in antioxidant enzyme activity can reflect the growth and metabolism of plants and resistance to environmental stress. Under high concentrations of As (20 and $\left.30 \mathrm{mg} \mathrm{L}^{-1}\right)$ stress, the activities of SOD, CAT and POD decreased in eucalyptus but the malondialdehyde (MDA) content increased significantly, and eucalyptus suffered severe oxidative damage (Meng et al., 2017).

Nowadays, exploring the prevention and control methods to combat As pollution is a hot topic in the interdisciplinary research of agricultural environment and biology (Dong et al., 2021; Zheng et al., 2022). Selenium (Se) is one of the essential nutrients and plays an essential physiological function in the human body. Se is an essential component of many proteins and enzymes, such as glutathione peroxidase (GSH-Px) and thioredoxin reductase (TR) (Diao et al., 2014). Certain organic forms of Se have antioxidant and anti-cancer functions (Rayman, 2005). Research proposes that Se has a significant alleviating effect on As toxicity and inhibits the anti-cancer properties of As (La porte, 2011). Other scholars have also reported the effects of Se on As toxicity in plants (Camara et al., 2018; Pandey and Gupta, 2018), tobacco (Han et al., 2015) and algae (Kramárová et al., 2012). However, these studies primarily focused on the effects of Se application on plants in a single form. However, comparative studies on the effects of Se in various forms (such as inorganic Se and organic Se) on As in plants are relatively lacking, and there are few reports on the effects of Se on As-contaminated vegetables.

Radish, which belongs to the cruciferous family of plant kingdom, has a short duration but high yield. It has been reported that radish absorbs and enriches As more than other daily used vegetables (Huang et al., 2006), and cruciferous vegetables, such as radish, have a higher Se enrichment capacity than other plants (Pedrero et al., 2006). Therefore, this study aimed to investigate the effects of organic and inorganic Se on the antioxidant activity and absorption of As as well as indicators of growth in As-stressed radish, and provided information to alleviate the health risks of As.

\section{Materials and Method}

\section{Pot experiment}

In this study, red soil and cherry radish were selected as experimental objects (Support Material, Figure S1). The pot experiment and management was carried out in accordance with our previous research (Hu et al., 2020, 2021). The experimental design included the following 21 treatments: (1) 30-mg As kg-1 (control group [CK]); (2) 30-mg As kg-1 + 1-mg Se kg-1 (1Se(IV)); (3) 30-mg As kg-1 + 3-mg Se kg-1 (3 Se(IV)); (4) 30-mg As kg-1 + 6-mg Se kg-1 (6Se(IV)); (5) 30-mg As kg-1 + 12-mg Se kg-1 (12Se(IV)); (6) 30-mg As kg-1 + 24-mg Se kg-1 (24Se(IV)); (7) 30-mg As $\mathrm{kg}^{-1}+1$-mg Se kg-1 (1Se(VI)); (8) 30-mg As kg-1 + 3-mg Se $\mathrm{kg}^{-1}$ (3Se(VI)); (9) 30-mg As kg-1 + 6-mg Se kg-1 (6Se(VI)); (10) 30-mg As kg-1 + 12-mg Se kg-1 (12Se(VI)); (11) 30-mg $\mathrm{As} \mathrm{kg}^{-1}+24-\mathrm{mg} \mathrm{Se} \mathrm{kg}{ }^{-1}(24 \mathrm{Se}(\mathrm{VI}))$; (12) 30-mg As kg-1 + 1 -mg Se kg-1 (1Se-Y); (13) 30-mg As kg-1 + 3-mg Se kg-1 (3Se-Y); (14) 30-mg As kg-1 + 6-mg Se kg-1 (6Se-Y); (15) $30-\mathrm{mg}$ As kg-1 + 12-mg Se kg-1 (12Se-Y); (16) 30-mg As $\mathrm{kg}^{-1}+24-\mathrm{mg} \mathrm{Se} \mathrm{kg}{ }^{-1}$ (24Se-Y); (17) 30-mg As kg-1 + 1-mg Se kg-1 (1Se-M); (18) 30-mg As kg-1 + 3-mg Se kg-1 (3Se$\mathrm{M})$; (19) 30-mg As kg-1 + 6-mg Se kg-1 (6Se-M); (20) 30-mg $\mathrm{As} \mathrm{kg}^{-1}+12-\mathrm{mg} \mathrm{Se} \mathrm{kg}^{-1}(12 \mathrm{Se}-\mathrm{M})$ and (21) 30-mg As kg-1 24-mg Se kg-1 (24Se-M). As and Se were added in the form of a solution comprising sodium arsenite (As(III)), sodium selenite $(\mathrm{Se}(\mathrm{IV}))$, sodium selenate $(\mathrm{Se}(\mathrm{VI}))$, selenium yeast (Se-Y) or Se malt (Se-M), which was then mixed into the soil. The soil moisture content was maintained at $60-80 \%$ of the maximum value. After 50 days of equilibration, the seeds were sown. Each treatment was replicated for three times, and the treatments were arranged in random blocks. Plump cherry radish seeds were selected and moistened with ultrapure water, and 10 seeds were distributed evenly in each pot, which were subsequently sprayed with ultrapure water. When the seeds had germinated and developed two true leaves, the seedlings were thinned, leaving three plants in each pot. The photoperiod was $15 \mathrm{~h} \mathrm{day}^{-1}$, and the light intensity was $270 \sim 360 \mu \mathrm{E} \mathrm{m}{ }^{-2}$ $\mathrm{s}^{-1}$. Furthermore, the indoor temperature was $23^{\circ} \mathrm{C}$ during the day and $18^{\circ} \mathrm{C}$ at night. After growing for 35 days, the cherry radish plants were harvested. Their roots, stems and leaves were collected separately, after which they were washed and blotted dry with filter paper. After weighing, the samples were put in a Ziploc bag and stored at $-80^{\circ} \mathrm{C}$. Radish seeds, Se-Y (containing 2,000-mg $\mathrm{kg}^{-1} \mathrm{Se}$ ) and Se-M (containing 1,600-mg Se kg-1) were purchased from a local market in Nanchang, Jiangxi, China.

\section{Determination of chlorophyll and malondialdehyde content}

The chlorophyll content (expressed as $\mathrm{mg} \mathrm{kg}^{-1}$ fresh weight $[\mathrm{FW}]$ ) of radish leaves was determined by the $95 \%$ 
ethanol extraction method (Saelee et al., 2012). Fresh radish leaves $(0.2 \mathrm{~g})$ were cut into small pieces. Then the sample was extracted with $20-\mathrm{mL} 95 \%$ ethanol in darkness for about $24 \mathrm{~h}$. Finally, the absorbance of samples was measured at 665,649 and $652 \mathrm{~nm}$, and the blank experiment was set up using 95\% ethanol.

The MDA content (expressed as mmol g-1 FW) was measured by thiobarbituric acid colorimetry according to the study conducted by Hashemi et al. (2010). Briefly, the radish root was cut and homogenized, then extracted with $0.1 \%(\mathrm{w} / \mathrm{v})$ trichloroacetic acid (TCA) in a pre-chilled pestle and mortar. The mixture was centrifuged at $15,000 \mathrm{~g}$ for $15 \mathrm{~min}$ at $4{ }^{\circ} \mathrm{C}$. The obtained supernatant $(250 \mu \mathrm{L})$ was mixed with $2-\mathrm{mL}$ thiobarbituric acid reagent, then boiled for $30 \mathrm{~min}$ in a water bath and centrifuged at $6,000 \mathrm{~g}$ for $10 \mathrm{~min}$. Finally, the absorbance of the subsample was tested at $532 \mathrm{~nm}$.

\section{Determination of SOD, POD and soluble protein}

Extract for enzymatic assays was prepared according to the study conducted by Bai et al. (2013). Fresh radish root samples $(0.05 \mathrm{~g})$ were homogenized using phosphate buffer $\left(100 \mathrm{mmol} \mathrm{L}^{-1}, \mathrm{pH} 6.8,10 \mathrm{~mL}\right)$ and centrifuged under $17,000 \mathrm{~g}$ for $15 \mathrm{~min}$ at $4^{\circ} \mathrm{C}$. The supernatant was used for assays of SOD, POD and soluble protein.

The SOD activity was assayed by using the photochemical nitrogen blue tetrazolium (NBT) method (Beauchamp and Fridovich, 1971). The 3-mL reaction mixture consisted of 50-mM phosphate buffer, $\mathrm{pH} 7.8$; 9.9-mM L-methionine; $57-\mu \mathrm{M}$ NBT; $0.025 \%$ (w/v) Triton $\mathrm{X}-100$ and $0.0044 \%(\mathrm{w} / \mathrm{v})$ riboflavin. The reaction was allowed to run for $15 \mathrm{~min}$. Blanks and controls were run in the same manner but without irradiation and enzyme, respectively. The absorbance was measured at $560 \mathrm{~nm}$. The unit of SOD activity (expressed as $\mathrm{U} \mathrm{g}^{-1} \mathrm{~h}^{-1} \mathrm{FW}$ ) was defined as being present in the volume of extract that inhibited the NBT photoreduction by $50 \%$.

The POD activity was measured by the method of guaiacol oxidation with guaiacol (Pan et al., 2006) as the substrate in a total volume of $3 \mathrm{~mL}$. The reaction mixture consisted of 50-mM potassium phosphate buffer (pH 6.1); $1 \%$ guaiacol; $0.4 \% \mathrm{H}_{2} \mathrm{O}_{2}$ and enzyme extract. The reaction was initiated by the addition of $\mathrm{H}_{2} \mathrm{O}_{2}$, and changes in the absorbance at $470 \mathrm{~nm}$ were recorded for $2 \mathrm{~min}$. Enzyme activity was calculated and expressed as $\mu \mathrm{g} \mathrm{g}^{-1} \mathrm{~min}^{-1} \mathrm{FW}$.

The soluble protein content (expressed as $\mathrm{mg} \mathrm{g}^{-1} \mathrm{FW}$ ) was quantified following the study conducted by Bradford (1976). For protein quantification, 1.0-mL extract was mixed with 5-mL Coomassie Brilliant Blue reagent, and vortexed for $30 \mathrm{~s}$. The absorbance of the sample was recorded at $595 \mathrm{~nm}$.

\section{Determination of proline}

The proline concentration (expressed as $\mu \mathrm{g} \mathrm{g}^{-1} \mathrm{FW}$ ) was measured by acid ninhydrin colorimetry (Leyva et al., 2011; Yin and Zhang, 2016). The radish root (0.2 g) sample was extracted with $3 \%$ sulfosalicylic acid $(5 \mathrm{~mL})$ in boiling water for $20 \mathrm{~min}$. After centrifugation, the supernatant $(2 \mathrm{~mL})$ was mixed with acetic acid $(3 \mathrm{~mL})$ and acid ninhydrin $(3 \mathrm{~mL})$. The mixture was then taken into boiling water for $40 \mathrm{~min}$. The cooled mixture was extracted with toluene $(5 \mathrm{~mL})$. The absorbance of the organic phase was determined at $520 \mathrm{~nm}$ using toluene as a blank.

\section{Determination of As in radish}

The total As content in radish roots, shoots and leaves was quantified by inductively coupled plasma mass spectrometry (ICP-MS; Agilent 7700x, USA). The sample pretreatment and detailed steps were performed according to the previously published method (Hu et al., 2019). In brief, the pre-ground raw radish samples were mineralized with nitric acid to analyze total As content. Each sample was filtered through a $0.45-\mu \mathrm{m}$ microfiltration membrane and stored at $4^{\circ} \mathrm{C}$ before ICP-MS analysis (Table 1 ).

\section{Statistical Analysis}

The data of biochemical index for radish samples were expressed as fresh weight. All assays were performed at least in triplicate. Data were summarized using mean values and standard deviations (SD) and analyzed statistically using analysis of variance (ANOVA) at a $95 \%$ confidence level (95\% CL) using SPSS 19.0.

Table 1. Instrument parameter of inductively coupled plasma mass spectrometry (ICP-MS).

\section{ICP-MS}

$\begin{array}{ll}\text { RF power } & 1,590 \mathrm{~W} \\ \text { Ar plasma gas flow } & 15.0 \mathrm{~L} \mathrm{~min}^{-1} \\ \text { Ar auxiliary gas flow } & 0.86 \mathrm{~L} \mathrm{~min}^{-1} \\ \text { Ar nebulizer gas flow } & 1.0-1.1 \mathrm{~L} \mathrm{~min}^{-1} \\ \text { He gas flow rate } & 4.2 \mathrm{~mL} \mathrm{~min}^{-1} \\ \text { Spray chamber temperature } & 2^{\circ} \mathrm{C} \\ \text { Isotopes monitored } & { }^{75} \mathrm{As} \\ \text { Integration time per isotope for elemental analysis } & 100 \mathrm{~ms} \\ \text { Acquisition mode for elemental analysis } & \text { Spectrum }\end{array}$

Note: The full name of RF is radio-frequency power. 


\section{Results and Discussion}

\section{The growth characteristics of radish}

Figure 1 shows the growth of radish in the control group, low Se treatment level (1Se) and high Se treatment level (24Se). It was observed that the growth of radish with organic Se source was better than that of inorganic Se source. In the $\mathrm{Se}(\mathrm{VI})$ treatment group, the growth of radish was significantly inhibited and root development was limited. It suggested that the organic Se (including Se-Y and Se-M) could significantly promote the growth of radish whereas the expected growth of radish was severely inhibited with the gradual increase of Se application in $\mathrm{Se}(\mathrm{VI})$ treatments. The present study suggests that the application of organic Se fertilizer was more beneficial for growth of plants than the application of inorganic Se fertilizer, which was consistent with previous reports (Surai and Dvorska, 2001; Wang and Lovell, 1997). Organic Se could effectively increase the content of organic matter and bioaccessible Se in the soil and improve the content of phosphorus and potassium to increase soil fertility and enhance the absorption and utilization of crop nutrients (Li et al., 2017). Studies have demonstrated that using organic Se fertilizer could significantly improve the growth and nutritional quality of grapes, increase the Se content and reduce the accumulation of heavy metals (Zhu et al., 2017).

In the current study, different exogenous Se had different effects on the growth of radish. The possible reason was that $\mathrm{Se}(\mathrm{IV})$ was slightly less mobile because of its ease of

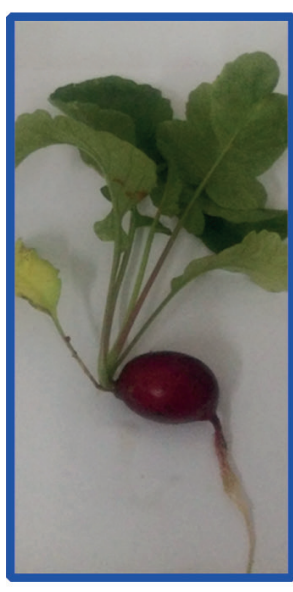

(A)

CK

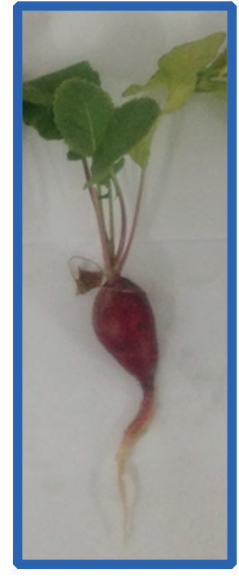

(B)

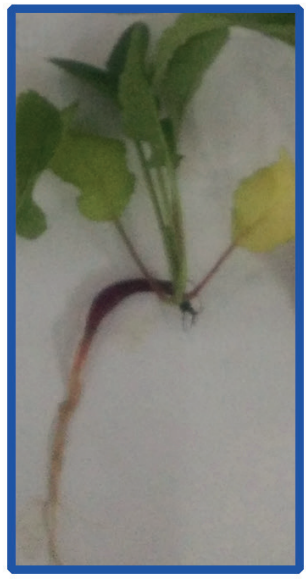

(C)

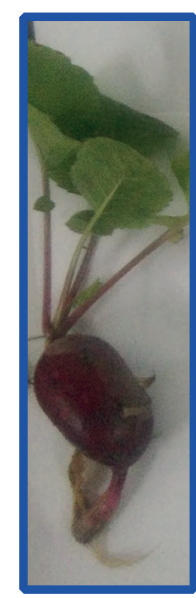

(D) $1 \mathrm{Se}-\mathrm{Y}$

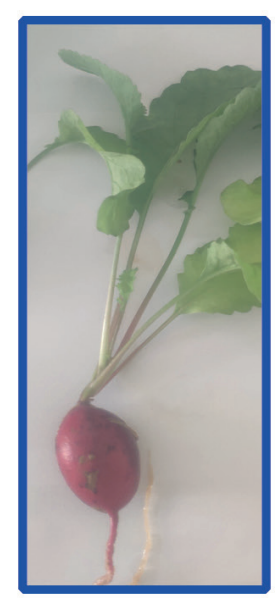

(E)

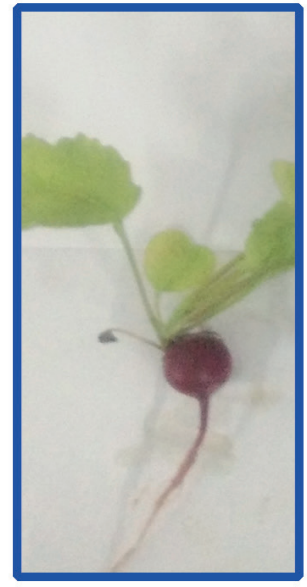

(F)

24Se(IV)

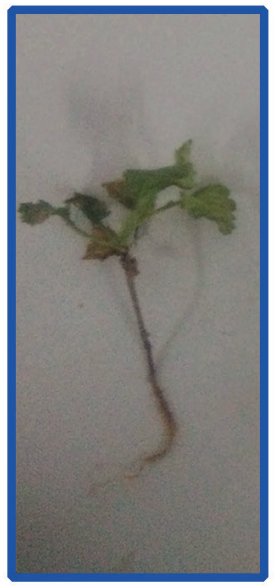

(C)

$24 \mathrm{Se}(\mathrm{VI})$

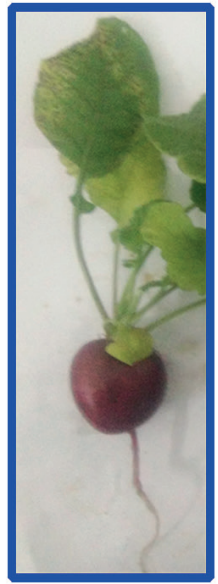

(D)

24Se-Y

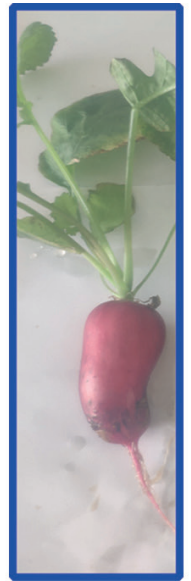

(E)

24Se-M

Figure 1. Radish growth in the CK, 1Se and 24Se treatment groups with application of different Se sources: sodium selenite (Se(IV)), sodium selenate (Se(VI)), selenium yeast (Se-Y) and selenium malt (Se-M). 
adsorption on the surface of soil particles whereas $\mathrm{Se}(\mathrm{VI})$ was more mobile and easily absorbed by plant roots within a short period; this caused the vegetable growth of radish to be limited. The two organic Se fertilizers applied to the soil were absorbed easily by the soil colloid and provided more organic nutrients. During plant growth, the fertilizer effect is gradually released through the action of microorganisms. Hence, the biomass of radish increased to varying degrees.

\section{Characteristics of chlorophyll content in radish}

Chlorophyll content determines plant's photosynthetic efficiency and is one of the crucial indicators reflecting the growth status of plants. As shown in Figure 2A, the chlorophyll content at $1 \mathrm{Se}$ and $3 \mathrm{Se}$ levels in the Se(IV) and $\mathrm{Se}(\mathrm{VI})$ treatment groups was significantly higher than the control group $(p<0.05)$, while it was opposite in the 24Se level.

Except for the 24Se level in the Se-M treatment group, the chlorophyll content in all organic Se treatments was higher than that in the control group $(p<0.05)$. With increase in the application of Se, the chlorophyll content of radish in the inorganic Se treatments decreased gradually, while that in the organic Se treatments increased in the beginning but decreased later. It was seen that the application of an appropriate amount of low Se concentration increased chlorophyll to improve the growth of radish, while the application of high Se concentration had an inhibitory effect on the growth of radish. Organic Se had a more pronounced effect on promoting radish growth than inorganic Se, and the tolerance concentration of radish to organic Se was higher than that of inorganic Se. Decrease of chlorophyll content in Se(VI) treatments depicted noticeable toxicological effects on radish growth. This could be related to different types of Se sources in the entire growth cycle of radish. Compared with organic Se, inorganic Se was characterized by immediate effect, short duration and vegetative growth stage. Higher concentrations of inorganic Se, especially $\mathrm{Se}(\mathrm{VI})$, inhibited the growth and development of radish, while Se nutrient deficiencies may exist during the reproductive growth stage. Hence, this could affect the chlorophyll content of radish to a certain extent.

Studies have established that the application of Se increased the chlorophyll content of wheat leaves, and the increase of chlorophyll content in the heading and flowering stages was higher than that in other stages (Chu et al., 2013). Magnesium and nitrogen are the primary components of chlorophyll, while copper, zinc, manganese and iron are involved in the biosynthesis of chlorophyll. Under As stress, the chlorophyll content of plants was decreased. This happened after As had entered the plant body, and the decreased concentration of chlorophyll was associated with hindered biosynthesis, and was not due to degradation (Mishra et al., 2016). Li et al. (2008) reported that As can replace $\mathrm{Mg}$ ions in chlorophyll molecules and interfere with the activity of chlorophyll synthetase, which hinders the synthesis of chlorophyll. The activity of chlorophyll enzymes is degraded and the chlorophyll is decomposed rapidly with the toxicity of As (Li et al., 2008). In general, soil Se application could increase the level of chlorophyll synthesis by promoting the absorption of mineral elements related to chlorophyll synthesis by plant leaves (Yao et al., 2009). Therefore, difference in the effects of different types of exogenous Se treatments on chlorophyll content in this study could be explained by different synergistic effects of various exogenous Se on mineral elements related to chlorophyll synthesis. Since the above results were only a reflection of the results of mature stage, the analysis of carotenoids in
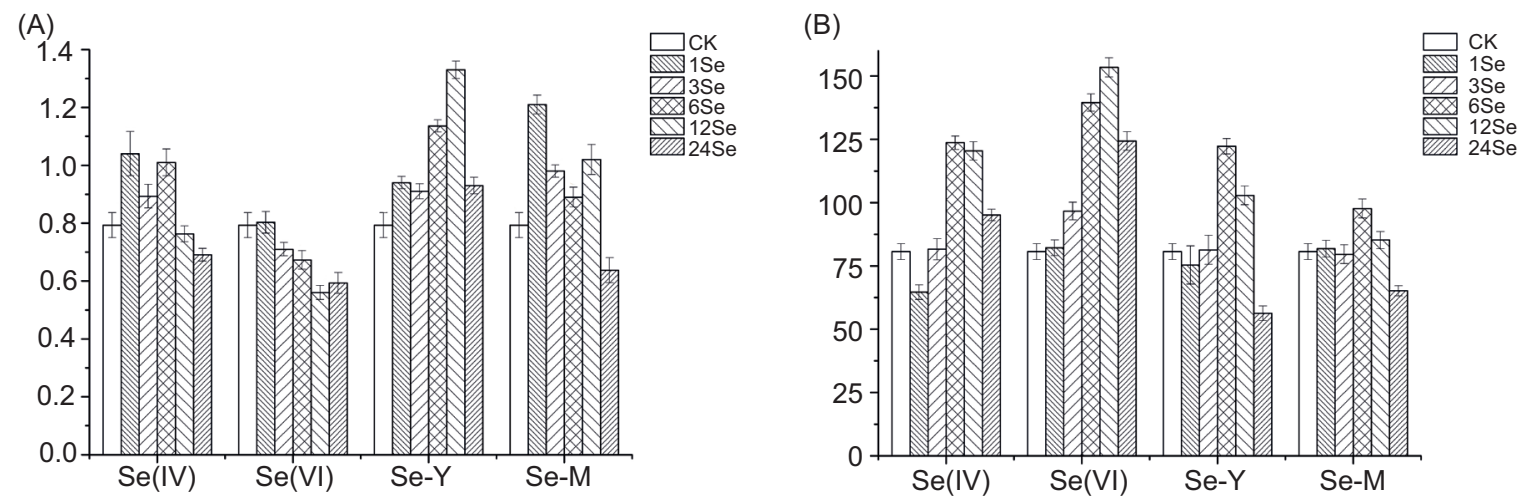

Figure 2. (A) Concentration of chlorophyll content in radish with application of different Se sources: sodium selenite (Se(IV)), sodium selenate $(\mathrm{Se}(\mathrm{VI}))$, selenium yeast (Se-Y) and selenium malt $(\mathrm{Se}-\mathrm{M})\left(\mathrm{mg} \mathrm{kg}^{-1} \mathrm{FW}\right)$. (B) The MDA content in radish with application of different Se sources: sodium selenite (Se(IV)), sodium selenate ( $\mathrm{Se}(\mathrm{VI}))$, selenium yeast (Se-Y) and selenium malt (Se-M) (mmol g-1 FW). 
leaves and the dynamic monitoring of chlorophyll at different stages of growth of radish must be strengthened in the future studies.

\section{Characteristics of MDA, SOD, POD, proline and soluble protein content in radish}

The MDA content indicates the degree of lipid peroxidation caused by ROS, and the MDA content of each Se treatment group presented a trend of initial increase and subsequent decrease (Figure 2B). In organic Se treatment groups, the MDA content reached the highest value at 6Se level with 122.24 for Se-Y treatment and 97.67 for Se-M treatment. The MDA content decreased to the lowest at the 24Se level, which was significantly lower than in the control group $(p<0.05)$. MDA is the end product of lipid oxidation which aggravates membrane damage. MDA content can be used as an essential indicator of cell lipid peroxidation, biofilm damage and plant stress resistance (Zhu et al., 2017).

The SOD activity at each level in the organic Se group was all higher than that in the control group $(p<0.05)$ (Figure 3A). In comparison with the control group, the highest value of SOD activity was in treatments of $6 \mathrm{Se}(\mathrm{IV}), 1 \mathrm{Se}(\mathrm{VI}), 12 \mathrm{Se}-\mathrm{Y}$ and $6 \mathrm{Se}-\mathrm{M}$, which increased by $49.27 \%, 22.37 \%, 59.63 \%$ and $84.23 \%$, respectively. The POD activity of Se(IV), Se-Y and Se-M treatment groups was higher than that of the control group $(p<0.05)$, while the $\mathrm{Se}(\mathrm{VI})$ group depicted the opposite trend (Figure $3 \mathrm{~B})$. In comparison to the control group, the highest value of POD activity was in $12 \mathrm{Se}$ (IV), $24 \mathrm{Se}-\mathrm{Y}$ and $12 \mathrm{Se}-\mathrm{M}$ treatments, which increased by $78.29 \%, 104.41 \%$ and $123.69 \%$, respectively, while the lowest value of POD activity in $\mathrm{Se}(\mathrm{VI})$ was at 565.25 at $1 \mathrm{Se}$ level. Compared with the other three kinds of exogenous $\mathrm{Se}, \mathrm{Se}(\mathrm{VI})$ evidently inhibited SOD, POD, proline and soluble protein in radish, depicting the toxicological effect of $\mathrm{Se}(\mathrm{VI})$ on radish. Both SOD and POD are antioxidant enzymes that scavenge excessive ROS in plants and protect cells from ROS poisoning, thus maintaining normal body metabolism.

The proline content initially increased in the Se(IV), Se-Y and Se-M treatment groups but decreased later, while in the $\mathrm{Se}(\mathrm{VI})$ treatment group, the proline content gradually increased with the increase of Se application levels (Figure $4 \mathrm{~A})$. In the $\mathrm{Se}(\mathrm{IV})$ treatment group, the proline content at the $3 \mathrm{Se}, 6 \mathrm{Se}$ and $12 \mathrm{Se}$ levels was significantly higher than that in the control group $(p<0.05)$. In the $\mathrm{Se}(\mathrm{VI})$ treatment group, the content of proline gradually decreased with the increase of Se content, but was lower than that in the control group $(p<0.05)$. The highest value of proline content was at $6 \mathrm{Se}$ level in Se-Y treatment group and at $12 \mathrm{Se}$ level in Se-M treatment group, which was 1.31 and 1.39 times, respectively, in comparison to the control group. It was reported that supplement Se could increase proline content in wheat (Khan et al., 2015) and enhance its resistance because of regulatory interaction between ethylene, proline and glutathione (gamma-glutamyl-cysteinyl-glycine [GSH]) metabolism.

The soluble protein content of Se(IV), Se-Y and Se-M treatment groups was significantly higher than that of the control group $(p<0.05)$ (Figuire $4 \mathrm{~b})$. There was no significant difference in the soluble protein content of each Se application level in the Se(IV) treatment group, while the Se-Y and Se-M treatments demonstrated a gradual increasing trend. The soluble protein content of the $\mathrm{Se}(\mathrm{VI})$ treatment group was significantly lower than that in the control group at high Se levels (12Se and 24Se levels; $p<0.05)$.

The above results indicate that resistance to As-contaminated radish varies with the application of
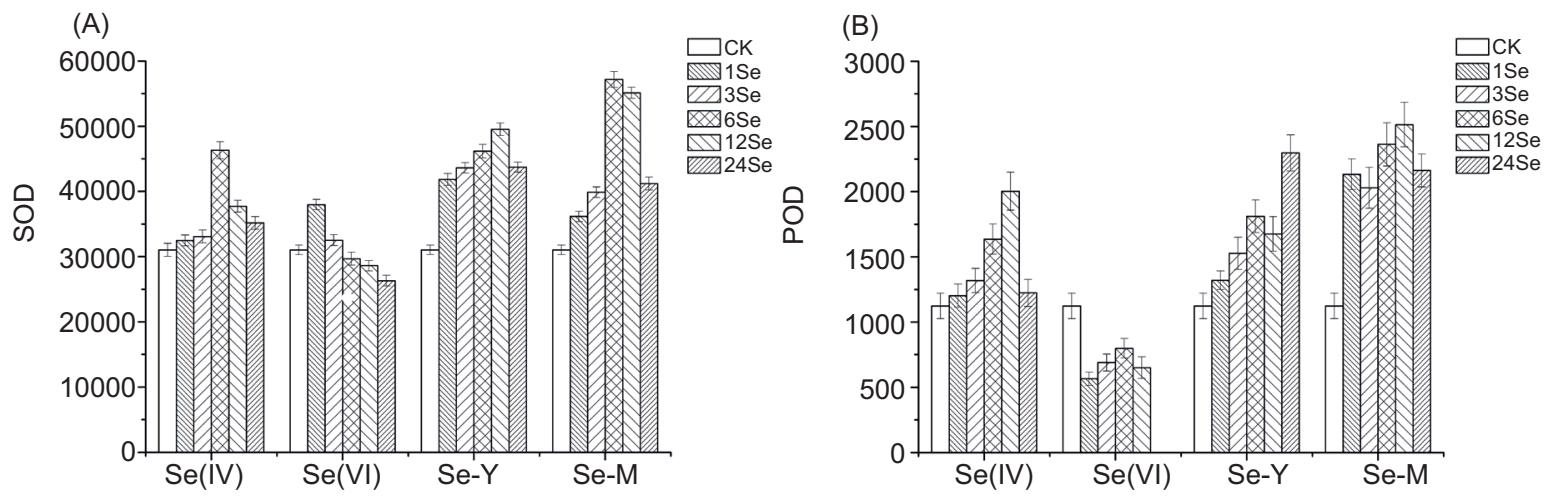

Figure 3. (A) The superoxide dismutase (SOD) activity in radish with application of different Se sources: sodium selenite (Se(IV)), sodium selenate (Se(VI)), selenium yeast (Se-Y) and selenium malt (Se-M) $\left(\mathrm{U} \mathrm{g}^{-1} \mathrm{~h}^{-1} \mathrm{FW}\right)$. (B) The peroxidase activity in radish with application of different Se sources: sodium selenite $(\mathrm{Se}(\mathrm{IV}))$, sodium selenate $(\mathrm{Se}(\mathrm{VI}))$, selenium yeast (Se-Y) and selenium malt (Se-M) ( $\left.\mathrm{g} \mathrm{g} \mathrm{g}^{-1} \mathrm{~min}^{-1} \mathrm{FW}\right)$. 
(A)

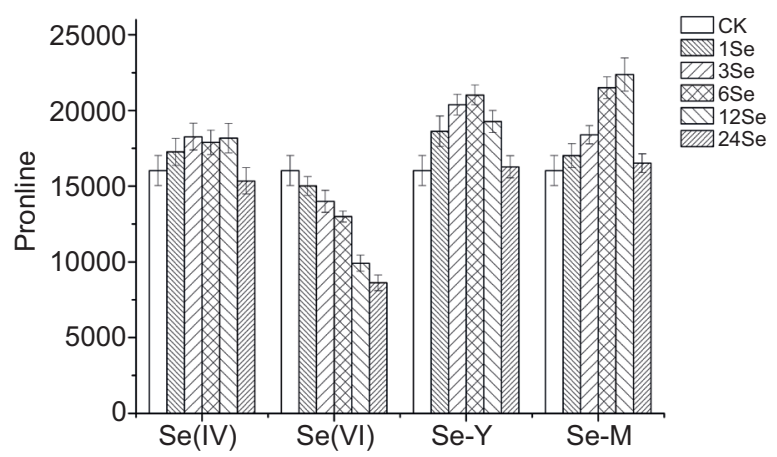

(B)

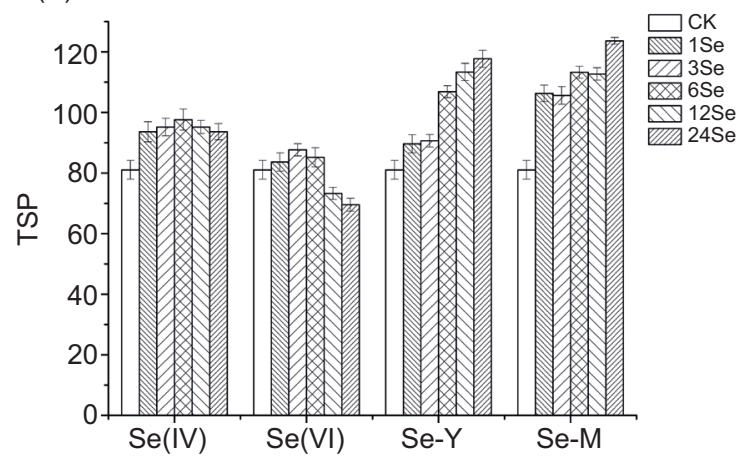

Figure 4. (A) The proline content in radish with application of different Se sources: sodium selenite (Se(IV)), sodium selenate $(\mathrm{Se}(\mathrm{VI}))$, selenium yeast (Se-Y) and selenium malt (Se-M) $\left(\mu \mathrm{g} \mathrm{g}^{-1} \mathrm{FW}\right)$. (B) The soluble protein content in radish with application of different Se sources: sodium selenite (Se(IV)), sodium selenate (Se(VI)), selenium yeast (Se-Y) and selenium malt (Se-M) (mg $\left.\mathrm{g}^{-1} \mathrm{FW}\right)$.

organic Se and Se(IV). It was observed that after Se was absorbed by radish, it participated in its metabolism and effectively enhanced the resistance of radish contaminated with As. However, its stress resistance varied with different forms of exogenous Se and its application level. Generally, Se is primarily involved in the antioxidant effect of plants in GSH-Px, and regulates the activities of various enzymes in plants and the synthesis of macromolecular substances such as proteins. It was reported that the CAT and POD activities, and proline and chlorophyll content, were significantly increased, while MDA content of wheat seedlings decreased with 1.0-, 2.0- and 3.0-mg Se $\mathrm{kg}^{-1}$ treatment (Yao et al., 2009). Application of low Se concentrations (5 and $10 \mu \mathrm{M}$ ) enhanced proline accumulation and antioxidative activity in cucumber seedlings (Hawrylak-Nowak, 2009).

The previous study indicated that application of Se significantly improved the proline, chlorophyll and protein content but reduced the MDA content in rice seedlings subjected to As stress (Pandey and Gupta, 2015). The observations indicated that seedlings supplemented only with As depicted inhibition in growth parameters. However, the application of Se improved the growth of rice seedlings, level of stress indicators (chlorophyll, protein and MDA content) and modulators (cysteine and proline) as compared to the individual treatment of As. The above reports indicated that Se treatment could enhance the resistance of plants to a certain extent.

In the present study, the MDA content in radish was higher than that in the control group with some treatments, indicating an increase in the activity and content of GSH-Px in radish by Se application, but was not enough to offset the As damage to plant cells. It was reported that adding the appropriate amount of Se $\left(0.1 \mathrm{mg} \mathrm{L}^{-1}\right)$ could reduce the toxicity of high-dose As
(5 mg L ${ }^{-1}$ ) (Han et al., 2015). Low Se levels (0.1 $\left.\mathrm{mg} \mathrm{L}^{-1}\right)$ reduce the toxicity of high As levels $\left(5 \mathrm{mg} \mathrm{L}^{-1}\right)$ by regulating the antioxidant system of flue-cured tobacco by reducing the transfer of $\mathrm{As}(\mathrm{III})$ from the root to the aerial part of the flue-cured tobacco (FCT), thereby promoting FCT growth.

Pandey and Gupta (2018) reported that Se supplementation could significantly reduce the content of $\mathrm{H}_{2} \mathrm{O}_{2}, \mathrm{NO}$ and ROS in rice. Se supplementation alleviated the toxicity of As and restored the nutritional deficiency of rice induced by As. Besides, Se treatment increased the activity of thiol metabolism-related enzymes. Yeh et al. (2003) reported that the mechanism of Se alleviating the toxicity of As was because Se could regulate glutathione peroxidase (GPX) activity. Malik et al. (2012) reported that Se could effectively inhibit the As absorption of mung bean plants, enhance their antioxidant and anti-stress properties, and alleviate the toxic effects of As on the stated plants. Plants treated with Se were also less affected by As-induced cell membrane, chlorophyll and cell viability.

In terms of the mechanism of Se alleviating the toxicity of As, following could be the different reasons: First, Se is involved in regulating antioxidant enzyme activity in plants. Se, as a component of seleno-enzyme activity centers such as GPX, can catalyze GSH to reduce peroxides in plants and participate in the scavenging of free radicals in plants, improve antioxidant enzymes such as SOD, POD, CAT, GPX, ascorbate peroxidase (APX) and dehydroascorbate reductase (DHAR) in plants, thus improving the antioxidant capacity and resistance to adversity in plants. Second, to a certain extent, Se may participate in energy and protein metabolism and interaction with other elements, or Se increases metallothionein (MTs), thiol and glutathione-s-transferase (GST) activity in the plant. Third, Se and As may produce a stable As-Se 
complex with low toxicity in plants, thus inhibiting the antioxidant damage caused by As in plants.

\section{Quantify the As content in roots, shoots and leaves of radish}

As shown in Figure 5, the content of As in roots, stems and leaves of radish was 3.93, 2.70, $1.61 \mathrm{mg} \mathrm{kg}^{-1}$, respectively, in the control group. The distribution characteristics of As content in radish was: roots > stems > leaves. From bottom to top, the As content depicted a decreasing trend. This pattern was entirely consistent with the results reported by Carbonell-Barrachina et al. (1999) and Smith et al. (2009). The content of As in the roots of plants was more significant than that in the upper part of the ground, which was due to the binding of As by phytochelatins, which restrict the upward migration of As (Smith et al., 2009). The content of As in radish in the $\mathrm{Se}(\mathrm{IV}), \mathrm{Se}(\mathrm{VI}), \mathrm{Se}-\mathrm{Y}, \mathrm{Se}-\mathrm{M}$ treatment groups was lower than that in the control group, which indicated that Se could significantly mimic the absorption of As in radish. In the Se(IV) treatment group, the content of As in the root of each treatment's radish depicted the initial decreasing and then increasing trend. However, the content of As in radish stems depicted a decreasing trend with the increase of Se application, while As in radish leaves depicted an initial increasing and then decreasing trend (Figure 5A). The Se(VI) treatment group indicated apparent toxicological effects of Se and inhibited the growth of radish roots, so the data were missed. The As content in radish leaves and stems at each treatment level demonstrated a gradually decreasing trend in $\mathrm{Se}(\mathrm{VI})$ treatment, while the As content in leaves, stems and roots at each treatment level gradually decreased in Se-Y treatments (Figures 5B and $\mathrm{C}$ ). In Se-M treatments, the distribution characteristics of the As content in roots, stems and leaves of radish tissues indicated a gradually decreasing trend with increased Se application (Figure 5D). The present study demonstrated that the application of Se(IV) and organic Se could alleviate the toxicological effects of As better than Se(VI). This result was consistent with the literature report (Camara et al., 2018). This could be because Se and As stimulated the response of plant antioxidant enzyme activities, thereby changing the translocation of heavy metal elements (Feng et al., 2013).

The relationship between different amounts of exogenous Se application and As in radish leaves, stems and roots is shown in Figures S2-S4 (Support Material). The content
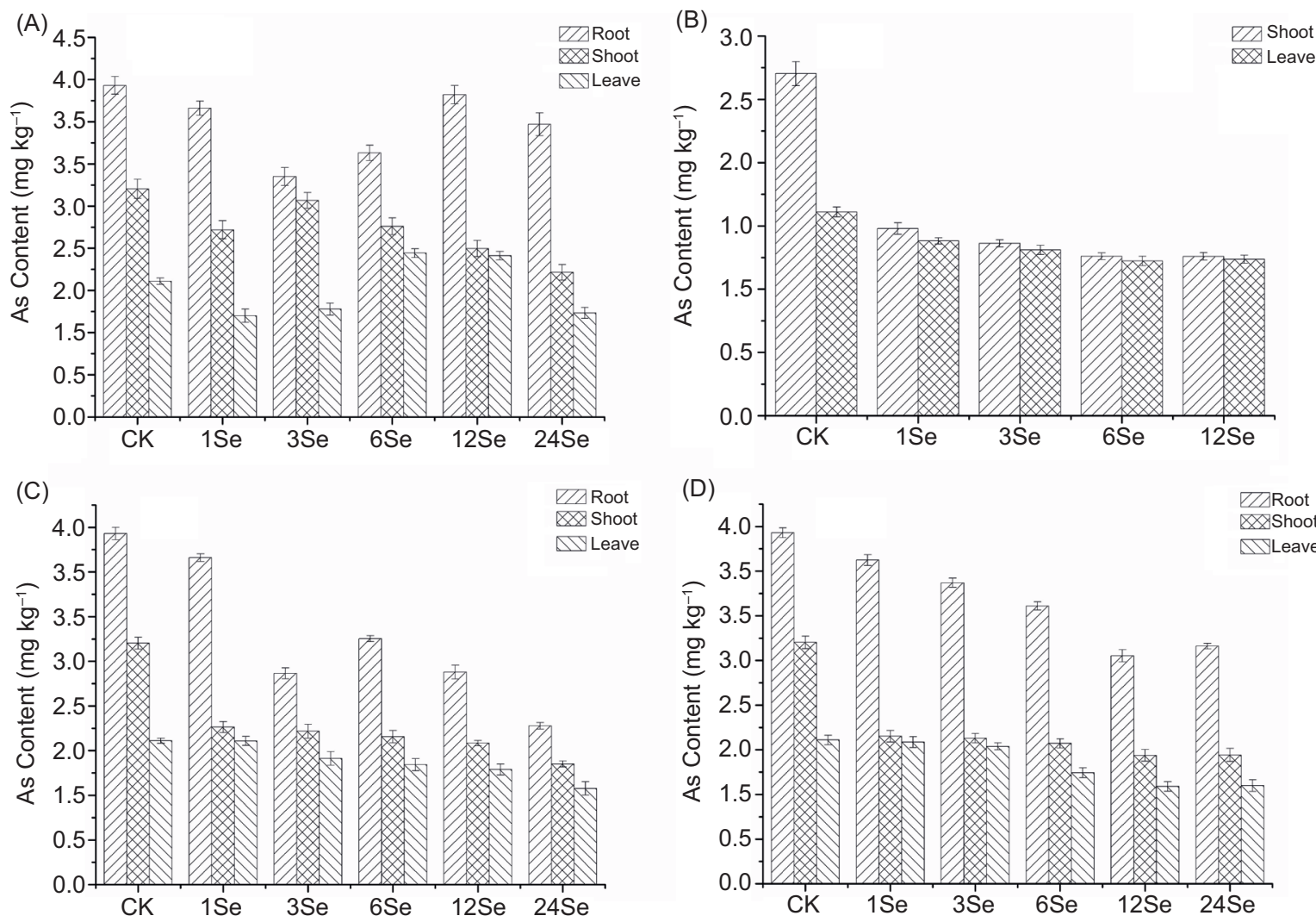

Figure 5. Arsenic concentration in radish roots, shoots and leaves with application of different Se sources: (A) sodium selenite (Se(IV)), (B) sodium selenate (Se(VI)), (C) selenium yeast (Se-Y) and (D) selenium malt (Se-M). 
of As in the roots of Se-Y treatment and the amount of Se added depicted a good correlation. The correlation coefficient $R^{2}$ was 0.9393 , which was better than the linear fitting degree of Se-M and Se(IV) treatments. The curve trend represents the changing trend of As content with increase in Se application. The As content in shoots with each Se treatment depicted a decreasing trend with increasing amount of Se application. The fitting curve coefficients of $\mathrm{Se}(\mathrm{IV}), \mathrm{Se}(\mathrm{VI}), \mathrm{Se}-\mathrm{Y}$ and $\mathrm{Se}-\mathrm{M}$ treatments were good. The values were $0.88396,0.98976$, 0.96823 and 0.9055 , respectively. In Se(IV) treatment, the changing trend of As in leaves depicted an initial increase and then decrease with the increased application of Se, while the other three Se treatments depicted a decreasing trend.

\section{Correlation analysis}

In $\mathrm{Se}(\mathrm{IV})$ treatments, the As content in roots was significantly negatively correlated with the As content in stems $(-0.544, p<0.05)$ (Support Material, Table S1). This indicates that As content has a competitive effect on roots and stems, possibly because of As and Se interaction, which limits the migration of As from roots to stems. The content of As in roots was significantly positively correlated with SOD activity and soluble protein content but was significantly negatively correlated with chlorophyll content. In $\mathrm{Se}(\mathrm{VI})$ treatments, the As content in stems and leaves was significantly positively correlated $(0.853, p<0.01)$ (Support Material, Table S2). In Se-Y treatments, the As content in roots was significantly negatively correlated with POD activity and soluble protein content (Support Material, Table S3). In Se-M treatments, the As content in roots was significantly positively correlated with the As content in stems and leaves. The content of As in roots was significantly negatively correlated with SOD $(-0.596, p<0.05)$ but significantly positively correlated with chlorophyll content $(0.612, p$ $<0.05$ ) (Support Material, Table S4). The above results demonstrate that after adding different concentrations of exogenous Se, the correlation between radish As content and plant enzymes is not entirely consistent. This is due to differences in the properties of different Se sources, leading to different chemical and biological effects of As and microorganisms on soil and plants. The results of ANOVA (Table 2) established that different Se sources, Se levels and their interaction factors have incredibly significant effects on As content and enzyme activities in various tissues of radish.

\section{Conclusion}

In this study, the influence of inorganic Se and organic Se was studied on the growth, physiological indexes and characteristic of As content on radish plant under As stress. The study demonstrated that supplementing Se at lower concentrations helped to improve the defense ability of radish against As toxicity. The results established that, except for $\mathrm{Se}(\mathrm{VI})$, the other three exogenous Se (including $\mathrm{Se}(\mathrm{IV}), \mathrm{Se}-\mathrm{Y}$ and $\mathrm{Se}-\mathrm{M}$ ) improved stress resistance in radish. Compared with inorganic Se treatment, organic Se treatment efficiently hindered the absorption of As in radish. Applying organic Se was more beneficial to radish growth than inorganic Se, while the application of $\mathrm{Se}(\mathrm{VI})$ demonstrated a significant toxic effect. It was observed that the agronomic effects of different exogenous Se applications were different, which provided a corresponding research basis for applying agricultural soil and crop Se fertilizer. At the same time, it provided related supporting material for the further development of As-Se interaction mechanism. Subsequent research on the mechanism of interaction between As and Se is required to provide theoretical basis for applying Se fertilizer and As pollution control in agriculture.

\section{Acknowledgments}

This work was financially supported by the National Key Research and Development Program of China (2017YFD0800900); National Natural Science Foundation of China (42162023); the Natural Science Foundation Project of Jiangxi Provincial Department of Science and Technology (20212BAB204042); College

Table 2. Analysis of two-factor variance of arsenic content and plant enzymes on radish tissues.

\begin{tabular}{|c|c|c|c|c|c|c|c|c|c|}
\hline \multirow[t]{2}{*}{ Factors } & \multicolumn{7}{|c|}{ Significance } & \multirow[t]{2}{*}{ proline } & \multirow[t]{2}{*}{ Chlorophyl } \\
\hline & $\begin{array}{l}\text { As content } \\
\text { in roots }\end{array}$ & $\begin{array}{l}\text { As content } \\
\text { in shoots }\end{array}$ & $\begin{array}{l}\text { As content } \\
\text { in leaves }\end{array}$ & MDA & SOD & POD & $\begin{array}{l}\text { Soluble } \\
\text { protein }\end{array}$ & & \\
\hline Se source & ** & ** & ** & ** & ** & ** & ** & ** & ** \\
\hline Se content & ** & ** & ** & ** & ** & ** & ** & ** & ** \\
\hline Se source $\times$ Se content & ** & ** & ** & ** & ** & $* *$ & ** & ** & ** \\
\hline
\end{tabular}


Students Innovation and Entrepreneurship Training Program of Jiangxi Province in 2020 (S202011319002); Teaching Reform Research Project of Nanchang Institute of Technology in 2020 (2020JG017); the Jiangxi Provincial Key Scientific Research Plan (20203BBGL73220); Research Foundation of Education Bureau of Jiangxi Province, China (GJJ201904); and Water Science and Technology Fund of Jiangxi Province in China (202124ZDKT15).

\section{Conflict of Interest}

There was no conflict of interest to disclose among authors.

\section{References}

Bai J.H., Liu J.H., Zhang N., Yang J.H., Sa R.L., and Wu L. 2013. Effect of alkali stress on soluble sugar, antioxidant enzymes and yield of oat. J Integr Agric. 12(8):1441-1449. https://doi. org/10.1016/S2095-3119(13)60556-0

Beauchamp C. and Fridovich I. 1971. Superoxide dismutase: improved assays and an assay applicable to acrylamide gels. Anal Biochem. 44(1):276-287. https://doi.org/10.1016/0003-2697(71)90370-8.

Bradford M.M. 1976. A rapid and sensitive method for the quantitation of microgram quantities of protein utilizing the principle of protein-dye binding. Anal Biochem. 72(1-2):248-254. https:// doi.org/10.1016/0003-2697(76)90527-3

Camara A.Y., Wan Y., Yu Y., Wang Q., and Li H. 2018. Effect of selenium on uptake and translocation of arsenic in rice seedlings (Oryza sativa L.). Ecotoxicol Environ Saf. 148:869-875. https:// doi.org/10.1016/j.ecoenv.2017.11.064

Carbonell-Barrachina A., Burlo F., and Valero D.1999. Arsenic toxicity and accumulation in turnip as affected by arsenic chemical speciation. J Agric Food Chem. 47(6):2288-2294. https://doi. org/10.1080/03601239909373220

Chu J., Yao X., Yue Z., Li J., and Zhao J. 2013. The effects of selenium on physiological traits, grain selenium content and yield of winter wheat at different development stages. Biol Trace Elem Res. 151(3):434-440. https://doi.org/10.1007/s12011-012-9575-6

Dahal B.M., Fuerhacker M., Mentler A., Shrestha R.R., and Blum W.E. 2008. Screening of arsenic in irrigation water used for vegetable production in Nepal. Arch Agron Soil Sci. 54(1):41-51. https://doi.org/10.1080/03650340701628197

Diao M., Ma L., Wang J., Cui J., Fu A., and Liu H.Y. 2014. Selenium promotes the growth and photosynthesis of tomato seedlings under salt stress by enhancing chloroplast antioxidant defense system. J Plant Growth Regul. 33(3):671-682. https://doi. org/10.1007/s00344-014-9416-2

Dong Y., Gao M., and Qiu W., 2021. Uptake of microplastics by carrots in presence of As (III): combined toxic effects. J Hazard Mater. 411(1):125055. https://doi.org/10.1016/j.jhazmat.2021.125055

Fendorf S., Michael H.A., and Van Geen A. 2010. Spatial and temporal variations of groundwater arsenic in south and southeast asia. Science. 328(5982):1123-1127. https://doi.org/10.1126/ science.1172974

Feng R., Wei C., and Tu S. 2013. The roles of selenium in protecting plants against abiotic stresses. Environ Exp Bot. 87(87):58-68. https://doi.org/10.1016/j.envexpbot.2012.09.002

Han D., Xiong S., Tu S., Liu J., and Chen C. 2015. Interactive effects of selenium and arsenic on growth, antioxidant system, arsenic and selenium species of Nicotiana tabacum L. Environ Exp Bot. 117:12-19. https://doi.org/10.1016/j.envexpbot.2015.04.008

Hashemi A., Abdolzadeh A., Sadeghipour H.R. 2010. Beneficial effects of silicon nutrition in alleviating salinity stress in hydroponically grown canola, Brassica napus L., plants. Soil Sci Plant Nutr. 56(2):44-253. https://doi.org/10.1111/j.1747-0765.2009.00443.x

Hawrylak-Nowak B. 2009. Beneficial effects of exogenous selenium in cucumber seedlings subjected to salt stress. Biol Trace Elem Res. 132(1-3):259-269. https://doi.org/10.1007/ s12011-009-8402-1

Hu L., Fan H.B., Wu D.S., Liao Y.C., Shen F.F., Liu W.F., Huang R.Z., Zhang B.J., and Wang X.L. 2020. Effects of selenium on antioxidant enzyme activity and bioaccessibility of arsenic in arsenic-stressed radish. Ecotoxicol Environ Saf. 200:110768. https:// doi.org/10.1016/j.ecoenv.2020.110768

Hu L., Wang X.L., Wu D.S., Zhang B.J., Fan H.B., Shen F.F., Liao Y.C., Huang X.P., and Gao G.Q. 2021. Effects of organic selenium on absorption and bioaccessibility of arsenic in radish under arsenic stress. Food Chem. 344:128614. https://doi.org/10.1016/j. foodchem.2020.128614

Hu L., Zhang B.J., Wu D.S., Fan H.B., Tu J., Liu W.F., Huang R.Z., and Huang X.P. 2019. Estimation of arsenic bioaccessibility in raw and cooked radish using simulated in vitro digestion. Food Funct. 10:1426-1432. https://doi.org/10.1039/C8FO02003E

Huang R.Q., Gao S.F., Wang W.L., Staunton S., and Wang G. 2006. Soil arsenic availability and the transfer of soil arsenic to crops in suburban areas in Fujian Province, southeast China. Sci Total Environ. 368(2-3):531-541. https://doi.org/10.1016/j. scitotenv.2006.03.013

Khan M.I.R., Nazir F., Asgher M., Per T.S., and Khan N.A. 2015. Selenium and sulfur influence ethylene formation and alleviate cadmium-induced oxidative stress by improving proline and glutathione production in wheat. J Plant Physiol. 173:9-18. https://doi.org/10.1016/j.jplph.2014.09.011

Kramárová Z., Fargašová A., Molnárová M., and Bujdoš M. 2012. Arsenic and selenium interactive effect on alga Desmodesmus quadricauda. Ecotoxicol Environ Saf, 86:1-6. https://doi. org/10.1016/j.ecoenv.2012.08.028

La Porte P.F. 2011. Selenium in the detoxification of arsenic: mechanisms and clinical efficacy. PhD Dissertation, The University of Chicago, Chicago, IL.

Leyva R., Sánchez-Rodríguez E., Ríos J.J., Rubio-Wilhelmi M.M., Romero L., Ruiz J.M., and Blasco B. 2011. Beneficial effects of exogenous iodine in lettuce plants subjected to salinity stress. Plant Sci. 181(2):195-202. https://doi.org/10.1016/j.plantsci.2011.05.007

Li Z., Liang D., Peng Q., Cui Z., Huang J., and Lin Z. 2017. Interaction between selenium and soil organic matter and its impact on soil selenium bioavailability: a review. Geoderma. 295:69-79. https://doi.org/10.1016/j.geoderma.2017.02.019 
Li S.F., Pu H.P., and Wang H.B. 2008. Advances in the study of effects of arsenic on plant. Photosynthesis Soils 3:6-12. https:// doi.org/10.1002/path.1700340417

Malik J.A., Goel S., Kaur N., Sharma S., Singh I., and Nayyar H. 2012. Selenium antagonises the toxic effects of arsenic on mungbean (Phaseolus aureus Roxb.) plants by restricting its uptake and enhancing the antioxidative and detoxification mechanisms. Environ Exp Bot. 77:242-248. https://doi.org/10.1016/j. envexpbot.2011.12.001

Mcbride M.B. 2013. Arsenic and lead uptake by vegetable crops grown on historically contaminated orchard soils. Appl Environ Soil Sci. 10:1-8. https://doi.org/10.1155/2013/283472

Meng M., Huang X.F., Li L., Luo Y.C., and Wang W.S. 2017. Effects of arsenic stress on activities of antioxidant enzymes of eucalyptus. Genomics Appl Biol. 12:79-85.

Mishra S., Alfeld M., Sobotka R., Andresen E., Falkenberg G., and Küpper H. 2016. Analysis of sublethal arsenic toxicity to ceratophyllum demersum: subcellular distribution of arsenic and inhibition of chlorophyll biosynthesis. J Exp Bot. 67(15):4639-4646. https://doi.org/10.1093/jxb/erw238

Pan Y., Wu L.J., and Yu Z.L. 2006. Effect of salt and drought stress on antioxidant enzymes activities and SOD isoenzymes of liquorice (Glycyrrhiza uralensis Fisch). Plant Growth Regul. 49(2-3):157165. https://doi.org/10.1007/s10725-006-9101-y

Pandey C. and Gupta M. 2015. Selenium and auxin mitigates arsenic stress in rice (Oryza sativa L.) by combining the role of stress indicators, modulators and genotoxicity assay. J Hazard Mater. 287:384-391. https://doi.org/10.1016/j.jhazmat.2015.01.044

Pandey C. and Gupta M. 2018 Selenium amelioration of arsenic toxicity in rice shows genotypic variation: a transcriptomic and biochemical analysis. J Plant Physiol, 231:168-181. https://doi. org/10.1016/j.jplph.2018.09.013

Pedrero Z., Madrid Y., and Cámara C. 2006. Selenium species bioaccessibility in enriched radish (Raphanus sativus): a potential dietary source of selenium. J Agric Food Chem. 54(6):24122417. https://doi.org/10.1021/jf052500n

Praveen A., Khan E., Ngiimei D.S., Perwez, M., Sardar M., and Gupta M. 2018. Iron oxide nanoparticles as nano-adsorbents: a possible way to reduce arsenic phytotoxicity in Indian mustard plant (Brassica juncea L.). J Plant Growth Regul. 37:612-624. https://doi.org/10.1007/s00344-017-9760-0

Rayman M.P. 2005. Selenium in cancer prevention: a review of the evidence and mechanism of action. Proc Nutr Soc. 64(4):527542. https://doi.org/10.1007/s00203-002-0478-3

Sae-Lee N., Kerdchoechuen O., and Laohakunjit N. 2012. Chemical qualities and phenolic compounds of Assam tea after soil drench application of selenium and aluminium. Plant Soil. 356(12):381-393. https://doi.org/10.1007/s11104-012-1139-1

Shri M., Kumar S., Chakrabarty D., Trivedi P.K., Mallick S., Misra P., and Tuli R. 2009. Effect of arsenic on growth, oxidative stress, and antioxidant system in rice seedlings. Ecotoxicol Environ Saf. 72(4):1102-1110. https://doi.org/10.1016/j.ecoenv.2008.09.022
Silva A.J., Nascimento C.W., Neto G., da Silva A., and Silva Junior E.A. 2015. Effects of silicon on alleviating arsenic toxicity in maize plants. Revista Brasileira de Ciência do Solo. 39(1):289296. https://doi.org/10.13140/RG.2.1.1934.7364

Smith E., Juhasz A.L., and Weber J. 2009. Arsenic uptake and speciation in vegetables grown under greenhouse conditions. Environ Geochem Health. 31(1):125-132. https://doi.org/10.1007/ s10653-008-9242-1

Su D., Li Y., and Gladyshev V.N. 2005. Selenocysteine insertion directed by the 3'-UTR SECIS element in Escherichia coli. Nucleic Acids Res. 33(8):2486-2492. https://doi.org/10.1093/ nar/gki547

Surai P. and Dvorska J. 2001. Is organic selenium better for animals than inorganic sources? Feed Mix. 9(5):8-10.

Tripathi P., Mishra A., Dwivedi S., Chakrabarty D., Trivedi P.K., Singh R.P., and Tripathi R.D. 2012. Differential response of oxidative stress and thiol metabolism in contrasting rice genotypes for arsenic tolerance. Ecotoxicol Environ Saf. 79:189-198. https://doi.org/10.1016/j.ecoenv.2011.12.019

Wang C. and Lovell R.T. 1997. Organic selenium sources, selenomethionine and selenoyeast, have higher bioavailability than an inorganic selenium source, sodium selenite, in diets for channel catfish (Ictalurus punctatus). Aquaculture. 152(1-4):223-234. https://doi.org/10.1016/S0044-8486(96)01523-2

Wu M.L., Li H.H., Jia Y.Y., Yang L.T., and Wang G. 2015. Influence of arsenic stress on the photosynthetic pigments and chlorophyll fluorescence characteristics of different tobacco cultivars. Asian J Ecotoxicolo. 10(3):216-223.

Yao X., Chu J., and Wang G. 2009. Effects of selenium on wheat seedlings under drought stress. Biol Trace Elem Res. 130(3):283-290. https://doi.org/10.1007/s12011-009-8328-7

Yeh J.Y., Cheng L.C., Liang Y.C., and Ou B.R. 2003. Modulation of the arsenic effects on cytotoxicity, viability, and cell cycle in porcine endothelial cells by selenium. Endothelium. 10(3):127-139. https://doi.org/10.1080/713715229

Yin B.F. and Zhang Y.M. 2016. Physiological regulation of Syntrichia caninervis Mitt. in different microhabitats during periods of snow in the gurbantünggüt desert, northwestern China. J Plant Physiol. 194:13-22. https://doi.org/10.1016/j.jplph.2016.01.015.

Zeng X.B., Li L.F., and Mei X.R. 2008. Heavy metal content in Chinese vegetable plantation land soils and related source analysis. Agric Sci China. 7(9):1115-1126. https://doi.org/10.1016/ S1671-2927(08)60154-6

Zheng X.M, Zhang Z.Y, Chen J.C., Liang H.T., Chen X., Qin Y. 2022. Comparative evaluation of in vivo relative bioavailability and in vitro bioaccessibility of arsenic in leafy vegetables and its implication in human exposure assessment. J Hazard Mater. 423:126909. https://doi.org/10.1016/j.jhazmat.2021.126909

Zhu S., Liang Y., Gao D., An X., and Kong F. 2017. Spraying foliar selenium fertilizer on quality of table grape (Vitis vinifera $L$.) from different source varieties. Sci Hortic. 218:87-94. https:// doi.org/10.1016/j.scienta.2017.02.025 


\section{Supplementary}
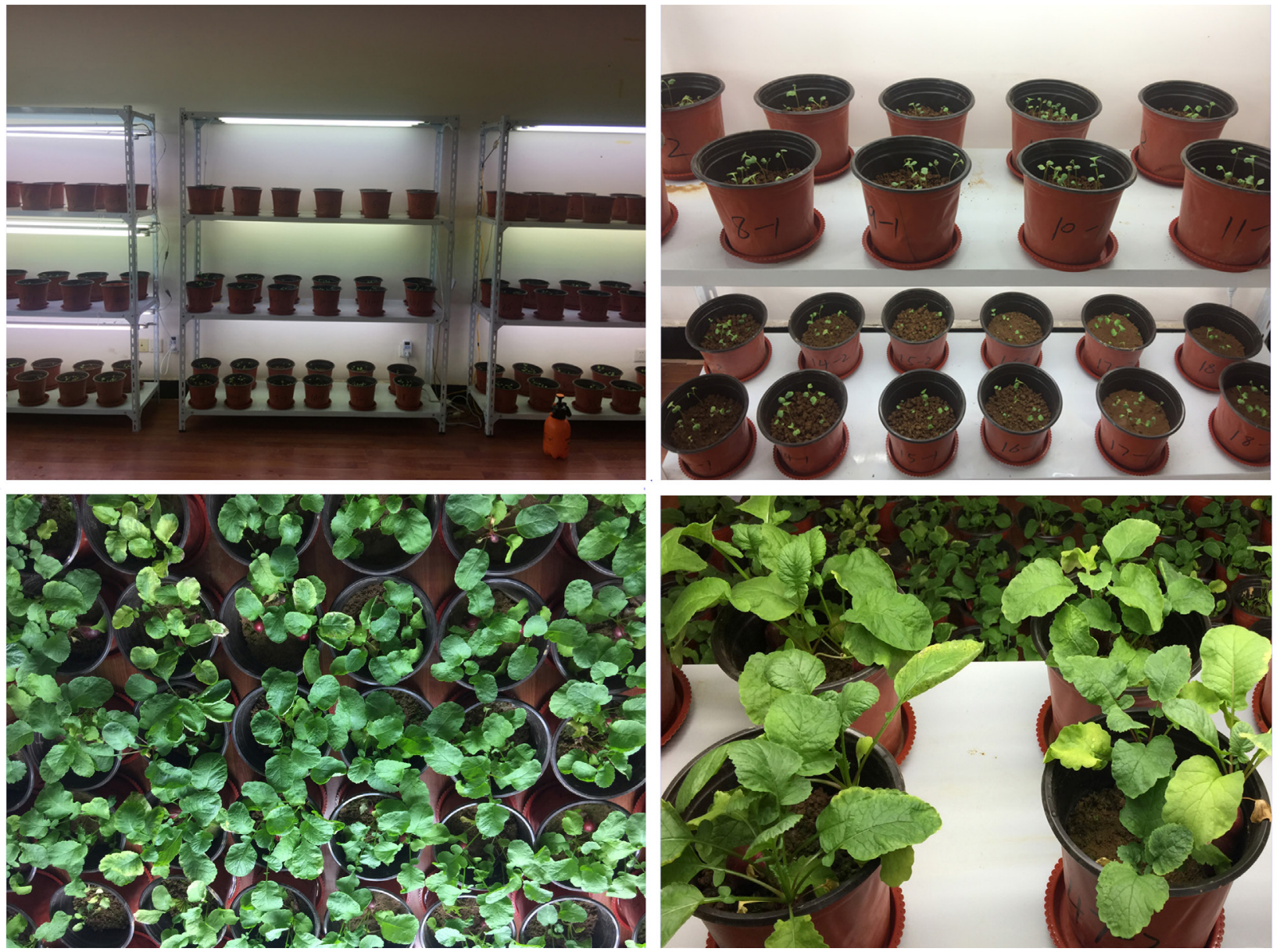

Figure S1. Pot experiment of radish with different Se sources application of sodium selenite (Se(IV)), sodium selenate (Se(VI)), selenium yeast (Se-Y) and selenium malt (Se-M).
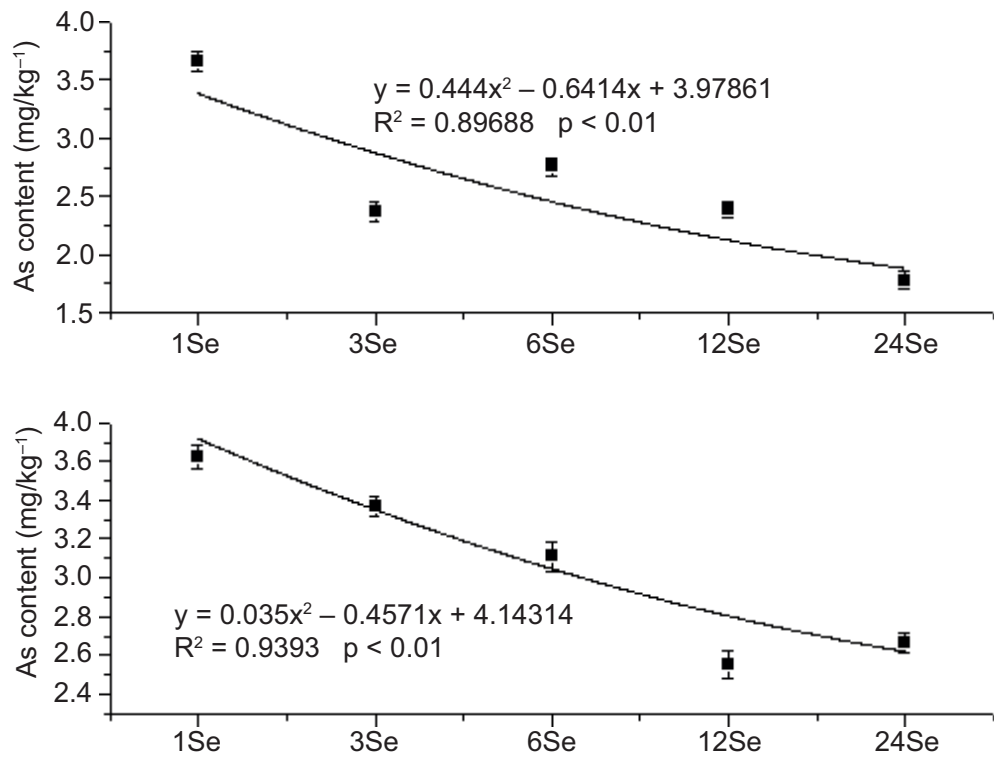

Figure S2. Relationship between arsenic content in radish roots and the adding amount of exogenous selenium of sodium selenite (Se(IV)), sodium selenate (Se(VI)), selenium yeast (Se-Y) and selenium malt (Se-M). 

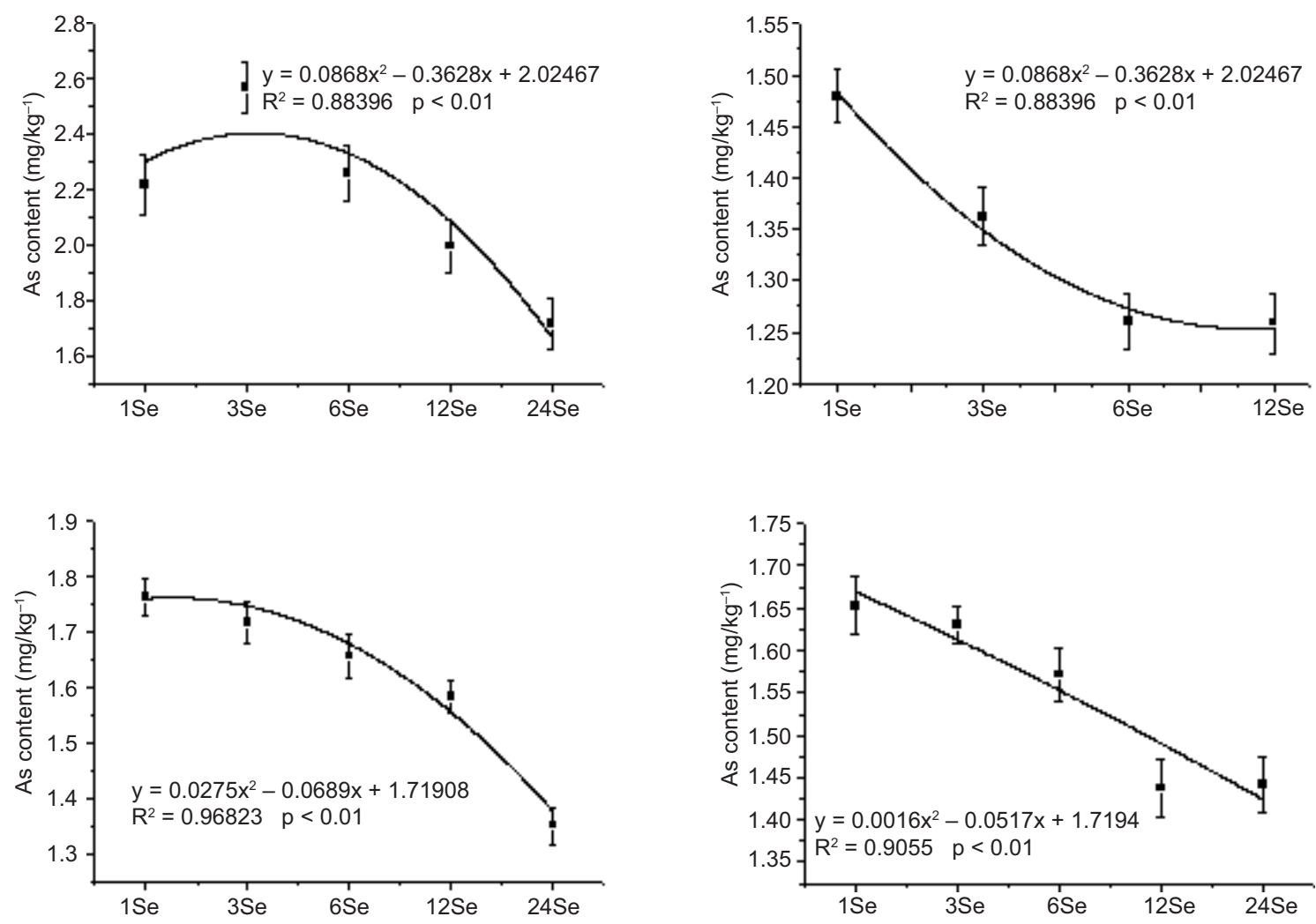

Figure S3. Relationship between arsenic content in radish shoot and the adding amount of exogenous selenium of sodium selenite (Se(IV)), sodium selenate (Se(VI)), selenium yeast (Se-Y) and selenium malt (Se-M).
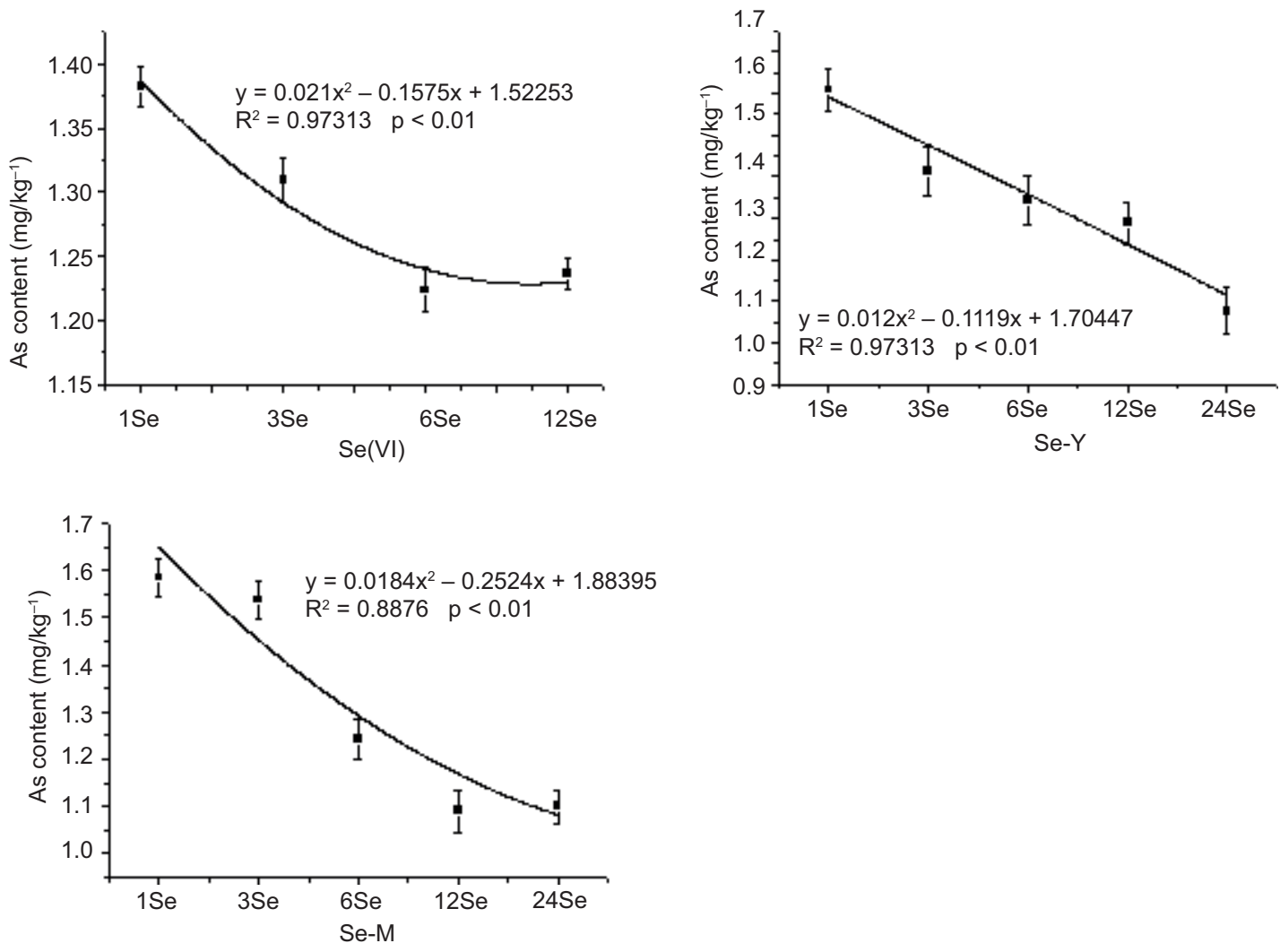

Figure S4. Relationship between arsenic content in radish leaves and the adding amount of exogenous selenium of sodium selenite (Se(IV)), sodium selenate ( $\mathrm{Se}(\mathrm{VI}))$, selenium yeast (Se-Y) and selenium malt (Se-M). 
Table S1. Correlation between arsenic and plant enzymes in radish after addition of selenite (Se(IV)) $(n=15)$.

\begin{tabular}{|c|c|c|c|c|c|c|c|c|c|}
\hline & $\begin{array}{l}\text { As content in } \\
\text { roots }\end{array}$ & $\begin{array}{l}\text { As content in } \\
\text { shoots }\end{array}$ & $\begin{array}{l}\text { As content in } \\
\text { leaves }\end{array}$ & MDA & SOD & POD & $\begin{array}{l}\text { Soluble } \\
\text { protein }\end{array}$ & Proline & Chlorophyll \\
\hline As content in roots & 1 & & & & & & & & \\
\hline As content in shoots & $-0.544^{*}$ & 1 & & & & & & & \\
\hline As content in leaves & 0.131 & -0.002 & 1 & & & & & & \\
\hline MDA & 0.180 & -0.198 & $0.959^{* *}$ & 1 & & & & & \\
\hline SOD & -0.158 & -0.002 & $0.830^{* *}$ & $0.865^{\star *}$ & 1 & & & & \\
\hline POD & 0.351 & -0.024 & $0.901^{* *}$ & $0.848^{* *}$ & $0.540^{*}$ & 1 & & & \\
\hline Soluble protein & -0.173 & 0.365 & $0.522^{*}$ & 0.430 & $0.539^{*}$ & 0.425 & 1 & & \\
\hline Proline & -0.093 & $0.736^{* *}$ & $0.478^{*}$ & 0.293 & 0.236 & $0.542^{*}$ & $0.582^{*}$ & 1 & \\
\hline Chlorophyll & -0.318 & $0.871^{* *}$ & -0.222 & -0.427 & -0.194 & -0.255 & 0.223 & $0.581^{*}$ & 1 \\
\hline
\end{tabular}

"It represents a significant correlation at the 0.01 level (one-sided). "It represents a significant correlation at the 0.05 level (one-sided).

Abbreviation: selenium (Se), arsenic (As), malondialdehyde (MDA), superoxide dismutase (SOD), peroxidase (POD).

Table S2. Correlation between arsenic and plant enzymes in radish after addition of selenate (Se(VI)) ( $n=15)$.

\begin{tabular}{|c|c|c|c|c|c|c|c|c|}
\hline & $\begin{array}{l}\text { As content in } \\
\text { shoots }\end{array}$ & $\begin{array}{l}\text { As content in } \\
\text { leaves }\end{array}$ & MDA & SOD & POD & $\begin{array}{l}\text { Soluble } \\
\text { protein }\end{array}$ & Proline & Chlorophyll \\
\hline As content in shoots & 1 & & & & & & & \\
\hline As content in leaves & $0.853^{* *}$ & 1 & & & & & & \\
\hline MDA & $-0.888^{* *}$ & $-0.856^{\star \star}$ & 1 & & & & & \\
\hline SOD & $0.973^{\star *}$ & $0.918^{\star *}$ & $-0.950^{* *}$ & 1 & & & & \\
\hline POD & $-0.580^{*}$ & $-0.593^{*}$ & 0.491 & $-0.537^{\star}$ & 1 & & & \\
\hline Soluble protein & 0.396 & 0.386 & $-0.609^{*}$ & $0.522^{*}$ & 0.324 & 1 & & \\
\hline Proline & $0.777^{\star *}$ & $0.720^{* *}$ & $-0.884^{* *}$ & $0.858^{* *}$ & -0.117 & $0.846^{* *}$ & 1 & \\
\hline Chlorophyll & $0.916^{\star *}$ & $0.808^{* *}$ & $-0.865^{* *}$ & $0.937^{\star *}$ & -0.338 & $0.644^{*}$ & $0.923^{* *}$ & 1 \\
\hline
\end{tabular}

${ }^{* *}$ It represents a significant correlation at the 0.01 level (one-sided). "It represents a significant correlation at the 0.05 level (one-sided).

Abbreviation: selenium (Se), arsenic (As), malondialdehyde (MDA), superoxide dismutase (SOD), peroxidase (POD).

Table S3. Correlation between arsenic and plant enzymes in radish after addition of selenium yeast (Se-Y) $(n=15)$.

\begin{tabular}{|c|c|c|c|c|c|c|c|c|c|}
\hline & $\begin{array}{l}\text { As content in } \\
\text { roots }\end{array}$ & $\begin{array}{l}\text { As content in } \\
\text { shoots }\end{array}$ & $\begin{array}{l}\text { As content in } \\
\text { leaves }\end{array}$ & MDA & SOD & POD & $\begin{array}{l}\text { Soluble } \\
\text { protein }\end{array}$ & Proline & Chlorophyll \\
\hline As content in roots & 1 & & & & & & & & \\
\hline As content in shoots & $0.772^{* *}$ & 1 & & & & & & & \\
\hline As content in leaves & $0.885^{\star *}$ & $0.861^{* *}$ & 1 & & & & & & \\
\hline MDA & 0.229 & 0.401 & 0.198 & 1 & & & & & \\
\hline SOD & -0.313 & -0.157 & -0.277 & $0.647^{* *}$ & 1 & & & & \\
\hline POD & $-0.777^{\star *}$ & $-0.847^{* *}$ & $-0.846^{\star *}$ & -0.209 & 0.211 & 1 & & & \\
\hline Soluble protein & $-0.687^{\star *}$ & $-0.806^{* *}$ & $-0.827^{\star *}$ & 0.072 & $0.596^{\star *}$ & $0.844^{* *}$ & 1 & & \\
\hline Proline & 0.332 & $0.691^{* *}$ & $0.477^{*}$ & $0.810^{* *}$ & 0.345 & -0.414 & -0.354 & 1 & \\
\hline Chlorophyll & -0.142 & -0.029 & -0.161 & $0.723^{* *}$ & $0.952^{* *}$ & 0.031 & $0.503^{*}$ & 0.357 & 1 \\
\hline
\end{tabular}

${ }^{*}$ It represents a significant correlation at the 0.01 level (one-sided). ${ }^{*}$ It represents a significant correlation at the 0.05 level (one-sided).

Abbreviation: selenium (Se), arsenic (As), malondialdehyde (MDA), superoxide dismutase (SOD), peroxidase (POD). 
Hu L et al.

Table S4. Correlation between arsenic and plant enzymes in radish after addition of malt selenium (Se-M) $(n=15)$.

\begin{tabular}{|c|c|c|c|c|c|c|c|c|c|}
\hline & $\begin{array}{l}\text { As content in } \\
\text { roots }\end{array}$ & $\begin{array}{l}\text { As content in } \\
\text { shoots }\end{array}$ & $\begin{array}{l}\text { As content in } \\
\text { leaves }\end{array}$ & MDA & SOD & POD & $\begin{array}{l}\text { Soluble } \\
\text { protein }\end{array}$ & Proline & Chlorophyll \\
\hline As content in roots & 1 & & & & & & & & \\
\hline As content in shoots & $0.872^{* *}$ & 1 & & & & & & & \\
\hline As content in leaves & $0.949^{* *}$ & $0.893^{\star *}$ & 1 & & & & & & \\
\hline MDA & 0.237 & 0.372 & 0.132 & 1 & & & & & \\
\hline SOD & $-0.543^{*}$ & -0.383 & $-0.619^{* *}$ & $0.663^{\star *}$ & 1 & & & & \\
\hline POD & $-0.530^{*}$ & -0.297 & $-0.513^{*}$ & $0.525^{*}$ & $0.786^{* *}$ & 1 & & & \\
\hline Soluble protein & $-0.730^{\star *}$ & $-0.596^{\star *}$ & $-0.746^{\star *}$ & -0.395 & 0.219 & 0.301 & 1 & & \\
\hline Proline & -0.368 & -0.142 & -0.355 & $0.764^{\star *}$ & $0.903^{\star *}$ & $0.837^{* *}$ & -0.044 & 1 & \\
\hline Chlorophyll & $0.617^{\text {** }}$ & $0.710^{\star *}$ & $0.620^{\star *}$ & $0.578^{*}$ & 0.042 & -0.077 & $-0.638^{* *}$ & 0.257 & 1 \\
\hline
\end{tabular}

"It represents a significant correlation at the 0.01 level (one-sided). "It represents a significant correlation at the 0.05 level (one-sided). Abbreviation: selenium (Se), arsenic (As), malondialdehyde (MDA), superoxide dismutase (SOD), peroxidase (POD). 